\title{
Hydrogeochemical assessment of groundwater in shallow aquifer of greater Noida region, Uttar Pradesh (U.P), India
}

\author{
Mohd. Saleem ${ }^{1} \cdot$ Athar Hussain $^{2} \cdot$ Gauhar Mahmood $^{3} \cdot$ Mohd. Waseem $^{3}$ \\ Received: 5 June 2016 / Accepted: 18 September 2018 / Published online: 27 September 2018 \\ (C) The Author(s) 2018
}

\begin{abstract}
Fresh water is needed for the survival of all living organisms to keep them healthy, safe and clean. Major part of this fresh water is obtained from groundwater. It is observed that the groundwater has been polluting due to anthropogenic activities and affecting the human beings, livestock soil nutrients by mass and environment in certain areas. The paper presents hydrogeochemical assessment of groundwater in shallow aquifers of Greater Noida region. Therefore, various physicochemical parameters such as $\mathrm{pH}$, TDS, EC, $\mathrm{TH}$ and major ions, i.e. $\mathrm{Cl}^{-}, \mathrm{SO}_{4}{ }^{2-}, \mathrm{NO}_{3}{ }^{-}, \mathrm{Na}^{+}, \mathrm{K}^{+}, \mathrm{Ca}^{2+}, \mathrm{Fe}^{2+}, \mathrm{Mg}^{2+}, \mathrm{CO}_{3}{ }^{2-}$ and $\mathrm{HCO}_{3}{ }^{-}$, have been analysed in the present study using standard procedures. The results of major constituents were compared with the water quality standards prescribed by WHO. From the analysed samples, different indices such as soluble sodium percentage (SSP), sodium adsorption ratio (SAR), residual sodium carbonate, magnesium adsorption ratio, Kelley's ratio and permeability index were characterized in the study. Results delineate that the groundwater is suitable for drinking and irrigational use.
\end{abstract}

Keywords Water quality · Groundwater pollution · Urban areas · Water indices

\section{Introduction}

Water is the most important resource for sustaining life on earth. Human or animal can live without food for few days but cannot live without water. Water is used in different ways such as drinking, bathing, washing, producing energy, irrigating the plants and is also used for recreation and transportation. Polluted water is unsuitable for mankind in terms of health and hygiene. The anthropogenic activities are deteriorating the water quality day by day. This water pollution is due to the rapid growth of population, industrialization and excessive usage of chemicals (Tiwari 2015). It is very important to ensure the quality of groundwater for

Mohd. Saleem

md.saleem0502@gmail.com

1 University Polytechnic, Faculty of Engineering and Technology, Jamia Millia Islamia, New Delhi 110025, India

2 School of Engineering, Gautam Buddha University, Greater Noida, U.P. 201308, India

3 Department of Civil Engineering, Faculty of Engineering and Technology, Jamia Millia Islamia, New Delhi 110025, India every human being for the safe health and survival on the earth (Chapman 1996).

Physical, chemical and biological parameters fix the quality of water. Groundwater is one of the most common source of drinking water supply and irrigational use for most of the population of India. Wastewater generated from class-I cities (having more than hundred thousand population) is about 29,000 million L/day and about $45 \%$ is generated from class-II towns (having fifty to hundred thousand population) by (Central Pollution Control Board, November 2005), while $35 \%$ is generated from metro-cities alone (Mangukiya et al. 2012). The influence of different water quality parameters has been elaborated by Brown et al. (1970). Anthropogenic activities are producing fluoride and arsenic pollution in the groundwater of different parts of India (CGWB 2010).

Farming activities in rural areas are the chief cause of groundwater pollution. Nitrate fertilizers are also increasing nitrate in groundwater (Muntean et al. 2006). The data-based model was formulated for groundwater quality monitoring strategies (Ishaku et al. 2011). Similar studies have also been evaluated in different parts of India by Bathrellos et al. (2008), Ahmed et al. (2002) and Stites and Kraft (2002). Due to rapid urbanization and its continually increasing population at an exponential rate, India has been facing the problem of deteriorating groundwater quality (Brindha et al. 
2011; Brindha and Elango 2010, 2011; Ramesh and Elango 2005).

Periodic changes in groundwater quality occur due to the origin and constitution of the recharged water, hydrological and human factors (Aghazadeh and Mogaddam 2002; Milovanovic 2007; Sreedevi 2002). Many research studies have been carried out by various researchers on water used for industrial activities, domestic and irrigational use (Vasanthavigar et al. 2010; Pritchard et al. 2008; Al-Futaisi et al. 2007; Jalali 2007; Mukherjee and Das 2007; Rivers et al. 1996). Investigation has been carried out on crystalline rocks to cope the needs for safe drinking water for vast population (Ahmed 2007; Lloyd 1999; Wright and Burgess 1992). Many authors have evaluated different geochemical processes in groundwater for governing of the chemical characteristics of such processes in many parts of the world (Nag and Ray 2015; Nag 2014; Nag and Ghosh 2013; Montety et al. 2008; Jalali 2002, Manjusree et al. 2009; Thilagavathi et al. 2012; Sivasubramanian et al. 2013; Nagaraju et al. 2014; Kumar et al. 2005; Islam et al. 2016a, b; Balaji et al. 2016).

Considering the above-mentioned facts in view, it is important to assess the groundwater quality of the area for domestic and irrigational purposes. The objective of this paper is to avail hydrochemical methods to determine the suitability of groundwater in the area for domestic as well as irrigation purposes.

\section{Materials and methods}

\section{Study area}

Greater Noida is one of the important city located in the Gautam Buddha Nagar district of the state Uttar Pradesh (India). It is located at a latitude of $28.4744^{\circ} \mathrm{N}$ and longitude of $77.5040^{\circ} \mathrm{E}$. It comprises of 124 villages with a population of 107,676 (till March 2014). The area of Greater Noida is about 40,000 hectares broadly bounded by national highway NH-24 in the north-west. The city comes under NCR (National capital Territory) region of Delhi and River Hindon flows in the western side of the city. During the last decade, the number of various industries in Greater Noida has grown more than 10 times (Greater Noida Master Plan 2001). Summer season starts from March and remains till July. During this period, the climate remains hot and average temperature ranges between 23 and $45^{\circ} \mathrm{C}$.

During mid-June to mid-September, the monsoon season gains with an average rainfall of $93.2 \mathrm{~cm}$ (36.7 in.), average temperature falls substantially down to as lower 3 to $4{ }^{\circ} \mathrm{C}$ at the apex of winter. The total land use cover is $13,570.00$ hectares with 30.0 hectares of commercial area and 1970.03 hectares of the total institutional area. The water supply in the area congregates through overhead tanks, tube wells, trunks and other supply lines. At present, nearly $460 \mathrm{~km}$ length of sewerage network, $500 \mathrm{~km}$ length of drainage and nearly $500 \mathrm{~km}$ length of water supply lines subsist in the area. Under phreatic conditions, groundwater occurred in shallow aquifers declines to the depth of $100 \mathrm{mbgl}$ in intermediate and it occurs in deeper aquifers under confined to semi-confined conditions. Groundwater monitoring wells have been established in the district to monitor the nature of water level and four times water table are being monitored in a year. Depth to water level of the study area can be divided into various zones on the basis of depth to water ranges. Water level varies from 3.35 to $14.40 \mathrm{mbgl}$ in phreatic aquifer whereas it exceeds greater than $9 \mathrm{mbgl}$ in most of the non-command areas of the study area. The general inclination of the area is from eastern side towards River Hindon in the west as shown through (Wikipedia Greater Noida) (Fig. 1).

\section{Sampling and analysis}

Groundwater samples were collected before pre-monsoon (April 2016) from various sources of shallow aquifers such as Government hand pumps (GHP), General hand pumps (HP) located in the study area (Franson 1992). The samples were analysed as per the methods prescribed in American Public Health Association manual (APHA-2320 1999). pH meter (micro processor $\mathrm{pH}$ meter, NIG334) was used to measure the $\mathrm{pH}$ of the groundwater samples. TDS, EC and salinity were measured by portable EC meter (NDC737). Standard EDTA method was used to determine $\mathrm{Ca}^{2+}$ and $\mathrm{Mg}^{2+}, \mathrm{Cl}^{-}$by standard $\mathrm{AgNO}_{3}$ titration, $\mathrm{HCO}_{3}{ }^{-}$by titration with $\mathrm{HCl}$. Flame photometry was used to evaluate $\mathrm{Na}^{+}$ and $\mathrm{K}^{+}$. Samples for major ions $\left(\mathrm{Na}^{+}, \mathrm{K}^{+}, \mathrm{Ca}^{2+}, \mathrm{Mg}^{2+}, \mathrm{Cl}^{-}\right.$, $\mathrm{SO}_{4}{ }^{2-}, \mathrm{NO}_{3}{ }^{-}$and $\mathrm{HCO}_{3}{ }^{-}$) were analysed by collecting the groundwater samples in $500 \mathrm{ml}$ polyethylene bottles. $\mathrm{Na}^{+}$ and $\mathrm{K}^{+}$were analysed by Gallenkamp Flame Analyser. $\mathrm{Ca}^{2+}$, $\mathrm{Mg}^{2+}, \mathrm{Cl}^{-}, \mathrm{SO}_{4}{ }^{2-}$ and $\mathrm{NO}_{3}{ }^{-}$were analysed by ICS-5000 DIONEX SP, ion chromatography (IC). To evaluate the suitability of the groundwater for agricultural purposes, soluble sodium percentage (SSP), sodium adsorption ratio (SAR), residual sodium carbonate (RSC), magnesium adsorption ratio (MAR), Kelley's ratio (KR) and permeability index (PI) were evaluated.

\section{Methods for hydrogeochemical and water quality evaluation}

Parameters such as $\mathrm{Ca}^{2+}$ and $\mathrm{Mg}^{2+}$ were considered to assess the water quality and geochemical process. The equation prescribed by Todd (1980), Ragunath (1987) and Hem (1991) has been used to determine the total hardness (TH) in ppm (Eq. 1): 


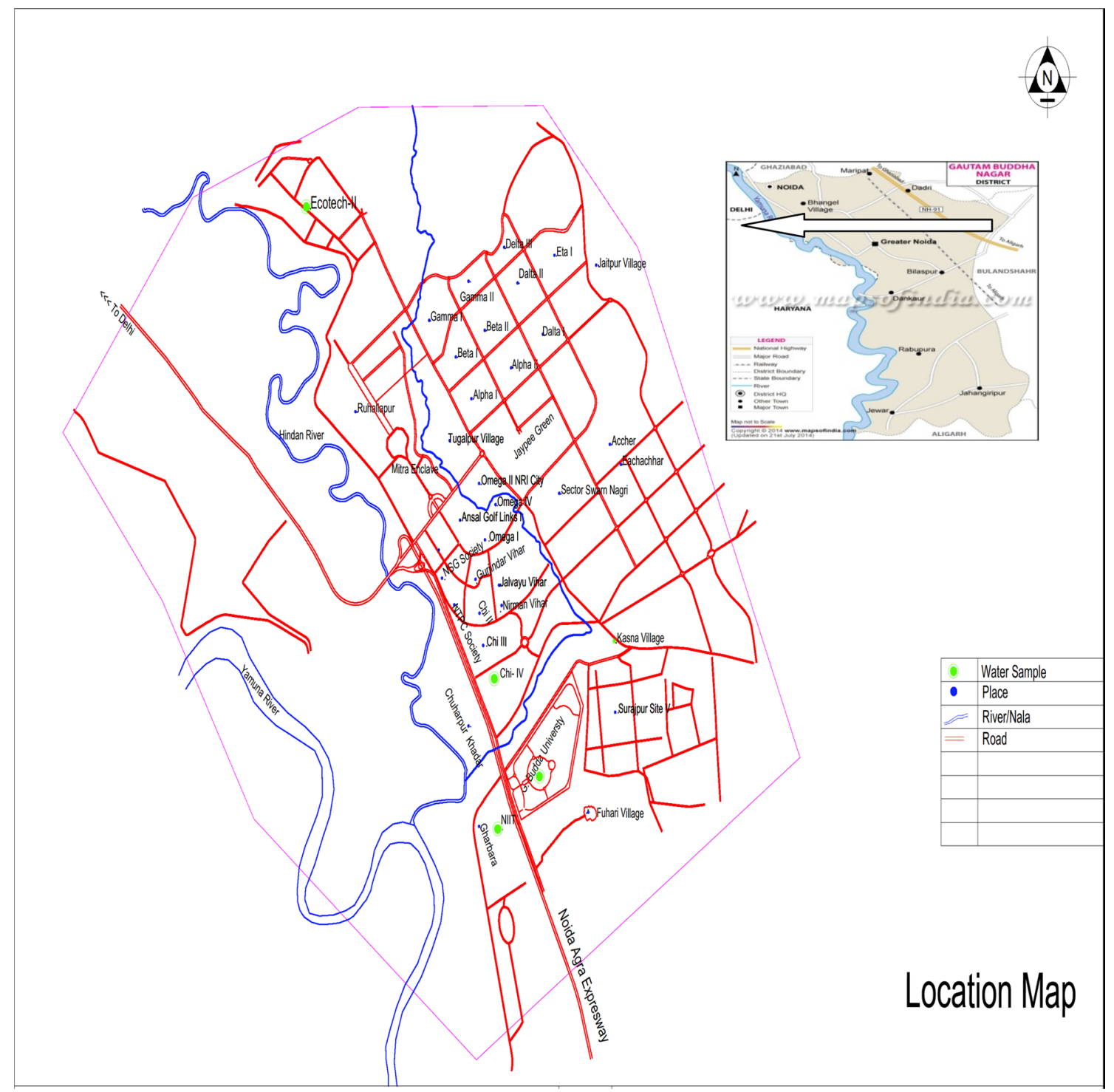

Fig. 1 Greater Noida map with locations of sampling sites of the study area. Source: Wikipedia

$\mathrm{TH}=2.497 \mathrm{Ca}^{2+}+4.115 \mathrm{Mg}^{2+}$

\section{Irrigation suitability}

Using the assessed water quality parameters, the following other parameters were determined in order to check the quality of the water used for irrigation:

1. Soluble sodium percentage (SSP).

2. Sodium adsorption ratio (SAR).

3. Residual sodium carbonate (RSC).

4. Magnesium adsorption ratio (MAR).
5. Kelley's ratio (KR).

6. Permeability index (PI).

\section{Soluble sodium percentage (SSP or $\mathrm{Na} \%$ )}

Sodium is normally expressed in terms of percentage of sodium or soluble sodium percentage ( $\% \mathrm{Na}$ ). Irrigation water is classified based on the reaction of sodium with soil. For assessing the suitability of water for irrigation purposes, percentage of $\mathrm{Na}^{+}$is widely used (Wilcox 1955). To evaluate the sodium hazard in soil, the term soluble sodium percentage 
(SSP) or Na \% is used. Todd (1980) explained soluble sodium percentage (SSP) or $\mathrm{Na} \%$ as (Eq. 2):

$\mathrm{SSP}$ or $\mathrm{Na} \%=\frac{\left(\mathrm{Na}^{+}+\mathrm{K}^{+}\right) \times 100}{\left(\mathrm{Ca}^{2+}+\mathrm{Mg}^{2+}+\mathrm{Na}^{+}+\mathrm{K}^{+}\right)}$

\section{Sodium adsorption ratio (SAR)}

SAR is a term used to express sodium or alkali hazard of the water quality for irrigation purpose (Bhuiyan et al. 2015; Islam et al. 2016a, b). Excess amount of $\mathrm{Na}^{+}$and low value of $\mathrm{Ca}^{2+}$ destroy the soil structure (Todd 1980). The SAR value of irrigation water expresses the relative proportion of $\mathrm{Na}^{+}$to $\mathrm{Ca}^{2+}$ and $\mathrm{Mg}^{2+}$ (Arajhi et al. 2015) and is calculated as (Eq. 3):

$\mathrm{SAR}=\frac{\mathrm{Na}^{+}}{\frac{\left(\mathrm{Ca}^{2+}+\mathrm{Mg}^{2+}\right)}{2}}$

However, the concentrations of $\mathrm{Na}, \mathrm{Ca}$ and $\mathrm{Mg}$ ions in water are expressed as $\mathrm{Na}^{+}, \mathrm{Ca}^{2+}$ and $\mathrm{Mg}^{2+}$, respectively (Ayers and Westcot 1985).

\section{Residual sodium carbonate (RSC)}

Considering the alkaline earths and weak acids, the residual sodium carbonate (RSC) is computed as per Ragunath (1987) and Rao et al. (2012) as (Eq. 4):

$$
\mathrm{RSC}=\left(\mathrm{CO}_{3}^{2-}+\mathrm{HCO}_{3}^{-}\right)-\left(\mathrm{Ca}^{2+}+\mathrm{Mg}^{2+}\right)
$$

\section{Magnesium adsorption ratio (MAR)}

MAR also recognized as magnesium hazard ( $\mathrm{MH})$ and is calculated as per method suggested by Ragunath (1987) as (Eq. 5):

$\operatorname{MAR}=\frac{\left(\mathrm{Mg}^{2+}\right) \times 100}{\left(\mathrm{Ca}^{2+}+\mathrm{Mg}^{2+}\right)}$

\section{Kelley's ratio (KR)}

Excess amount of sodium over calcium and magnesium is determined by Kelley's ratio (KR). To find out the suitability of groundwater for irrigation, Kelley's ratio equation (Kelley 1963) can be used as (Eq. 6):

$\mathrm{KR}=\frac{\mathrm{Na}^{+}}{\left(\mathrm{Ca}^{2+}+\mathrm{Mg}^{2+}\right)}$

\section{Permeability index (PI)}

Due to the long-term use of irrigation water, the permeability of soil gets influenced by sodium, calcium, magnesium and by carbonate contents in the soil. Permeability index (PI) of the groundwater samples was determined by using the formula given by Doneen (1964) (Eq. 7):

$\mathrm{PI}=\frac{\mathrm{Na}^{+}+\left(\mathrm{HCO}_{3}^{-}\right)}{\left(\mathrm{Ca}^{2+}+\mathrm{Mg}^{2+}+\mathrm{Na}^{+}\right)} \times 100$

All ionic concentrations are represented in milliequivalent per lire $(\mathrm{meq} / \mathrm{L})$. All these hydrogeochemical parameters were compared with national and international standards to assess the groundwater suitability for drinking and irrigation purposes (Table 1).

\section{Results and discussion}

\section{Drinking water suitability}

\section{$\mathrm{pH}$}

$\mathrm{pH}$ value is defined as the logarithm of the reciprocal of the $\mathrm{H}^{+}$ion concentration. It determines the nature of the solution whether it is acidic or alkaline. The strength of water is represented by $\mathrm{pH}$ and is controlled by $\mathrm{CO}_{2}, \mathrm{CO}_{3}{ }^{2-}$ and $\mathrm{HCO}_{3}{ }^{-}$concentrations (Hem 1991). The acceptable limit of $\mathrm{pH}$ for drinking water varies from 6.5 to 8.5 . Higher $\mathrm{pH}$ values above the permissible limit affect the mucous membrane of cells (WHO 2012). The pH of the study area is slightly alkaline and is ranging from 7.27 to 8.08 with a mean value of 7.53 (Fig. 2).

\section{Chloride concentration}

Chlorides are found in natural water due to leaching of chloride containing rocks and soils discharges of effluents from chemical industries, ice cream plant effluent, sewage disposal and irrigation drainage. Concentration greater than $250 \mathrm{mg} / \mathrm{L}$ is associated with sodium which exerts salty taste to the water. Chloride determination in natural water is useful in the selection of water supplies for human use. Higher concentration of chloride is harmful to heart and kidney diseases. Indigestion, taste, palatability and corrosion are also affected. The desirable limit of chloride in water is $250 \mathrm{mg} / \mathrm{L}$ (WHO 2012). The chloride ion concentration of the study area varies from 34 to $138 \mathrm{mg} / \mathrm{L}$ with a mean value of $94 \mathrm{mg} / \mathrm{L}$ (Fig. 3).

\section{Total hardness}

Hardness due to bicarbonate of calcium or magnesium is termed as temporary hardness and the hardness due to chloride, sulphates and nitrates of calcium and magnesium is 


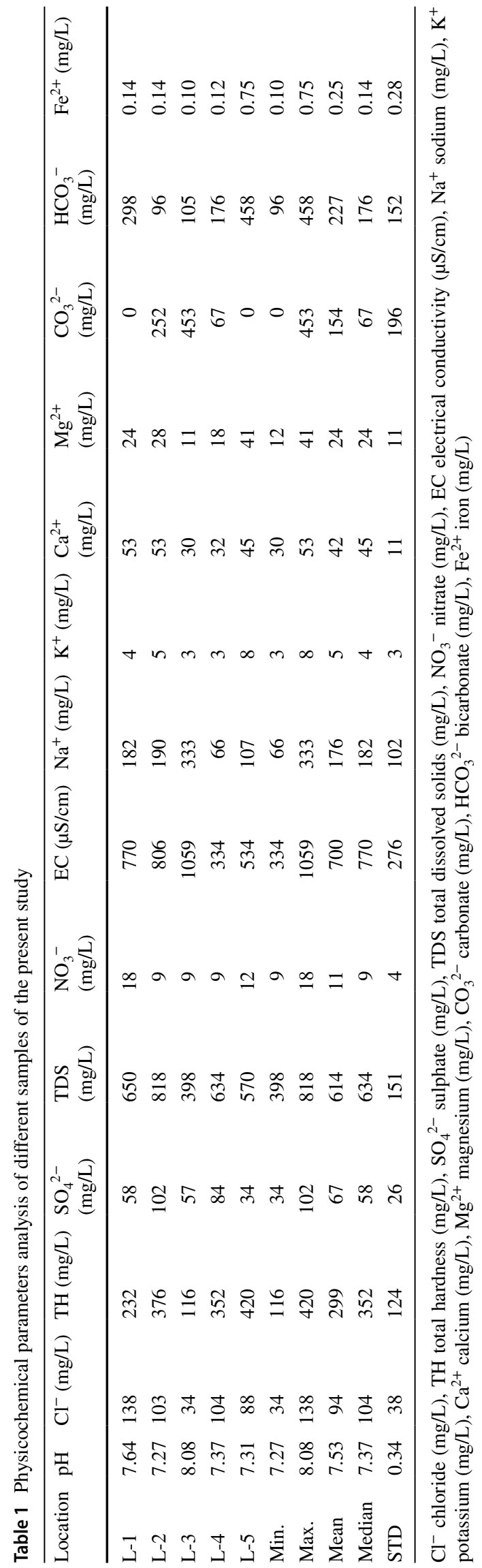

considered as permanent hardness. The permanent hardness results in greater amount of soap consumption. It leads to the calcification of arteries in human being as well as affects water supply system by forming scale. The acceptable limit is $200 \mathrm{mg} / \mathrm{L}$ (WHO 2012). The total hardness of the study area ranges from 116 to $420 \mathrm{mg} / \mathrm{L}$ with a mean concentration value of $299 \mathrm{mg} / \mathrm{L}$ (Fig. 3).

\section{Sulphate concentration}

Sulphate governs the synthesizing and degradation of proteins. The leaching of sulphates into the shallow groundwater increases more than $500 \mathrm{mg} / \mathrm{L}$. The recommended upper limit of sulphate in water for human consumption is $200 \mathrm{mg} / \mathrm{L}$ (WHO 2012). Gastrointestinal irritation is produced due to high concentration of sulphate. The sulphate ion concentration of the study area varies from 34.28 to $102.46 \mathrm{mg} / \mathrm{L}$ with a mean value of $67.07 \mathrm{mg} / \mathrm{L}$ (Fig. 4).

\section{Total dissolved solids}

Estimation of total dissolved solids (TDS) helps in testing the suitability of water for drinking, agriculture and industrial purpose. TDS is the sum of potassium, calcium, sodium, magnesium, carbonates, bicarbonates, chlorides, organic matter, phosphate and other particles. The acceptable limit is $500 \mathrm{mg} / \mathrm{L}$ (WHO 2012). The total dissolved solids concentration of the study area varies from 398 to $818 \mathrm{mg} / \mathrm{L}$ with a mean value of $614 \mathrm{mg} / \mathrm{L}$ (Fig. 3).

\section{Nitrate concentration}

Nitrate is found in groundwater due to leaching of nitrate with the percolating water through the soil. Sewage and other wastes rich in nitrates generally contaminate the groundwater. The disease methemoglobinemia found in infants is produced due to high concentration of nitrates in drinking water. It affects cardiovascular system and nervous system and also produces gastric cancer. The concentration should not exceed beyond $45 \mathrm{mg} / \mathrm{L}$ (WHO 2012). The nitrate concentration of the study area varies from 9 to $18 \mathrm{mg} / \mathrm{L}$ with a mean value of $11 \mathrm{mg} / \mathrm{L}$ (Fig. 4).

\section{Electrical conductivity}

The electrical conductivity is a measure of capacity of a substance or a solution to carry an electric current. Dissolved and dissociated substances parameters are measured by electrical conductivity. Temperature, ionic valences and ionic mobility affect the conductivity. Electrical conductivity 
Fig. 2 Variation of $\mathrm{pH}$ values at different locations of the present study

Fig. 3 Variation of $\mathrm{Cl}^{-}$, TH, TDS, $\mathrm{CO}_{3}{ }^{2-}$ and $\mathrm{HCO}_{3}^{-}$concentrations at different locations

Fig. 4 Variation of $\mathrm{SO}_{4}{ }^{2-}$, $\mathrm{NO}_{3}{ }^{-}, \mathrm{Na}^{+}, \mathrm{Ca}^{2+}$ and $\mathrm{Mg}^{2+}$ concentrations at different locations
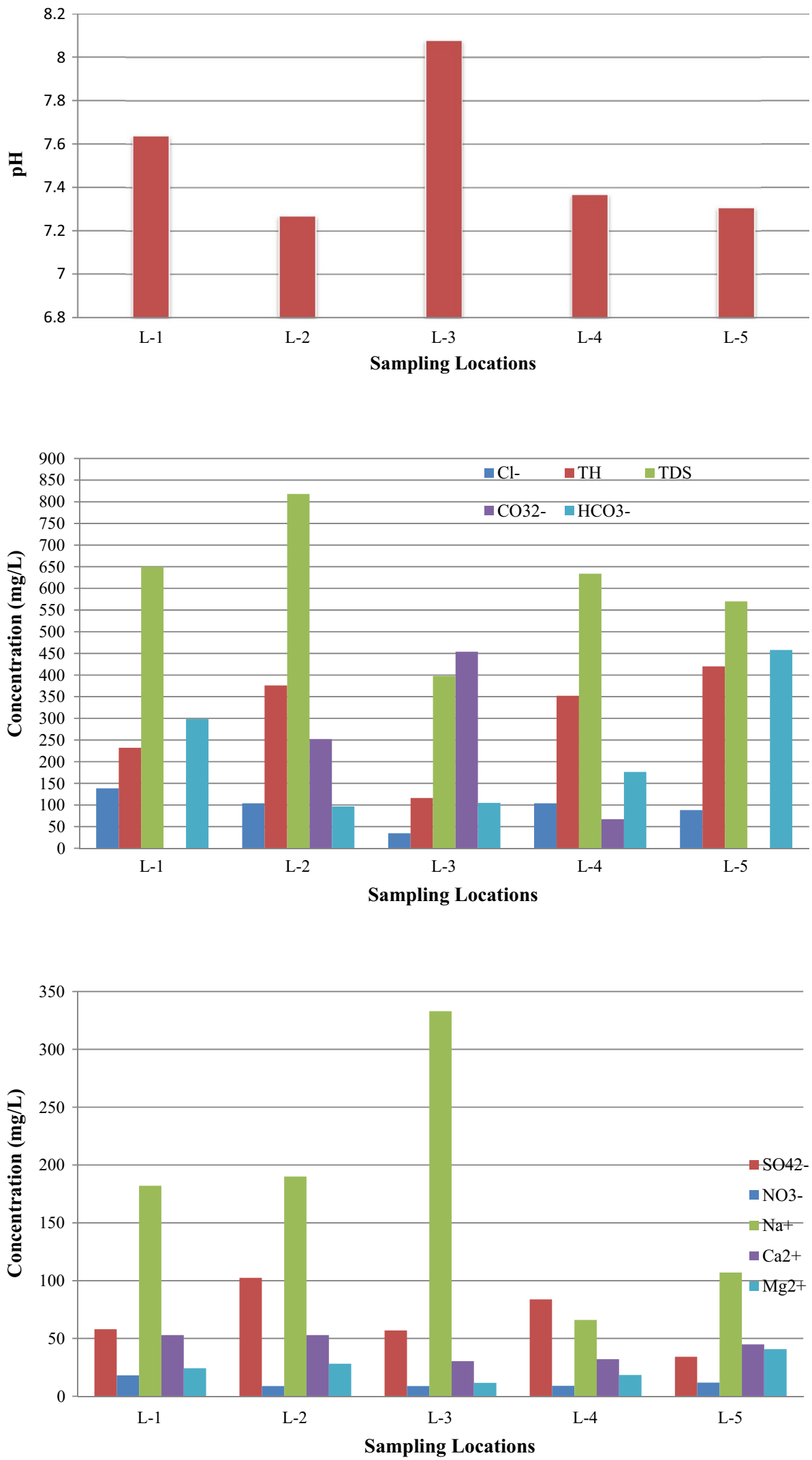
Fig. 5 Variation of electrical conductivity at different sampling locations of the study area

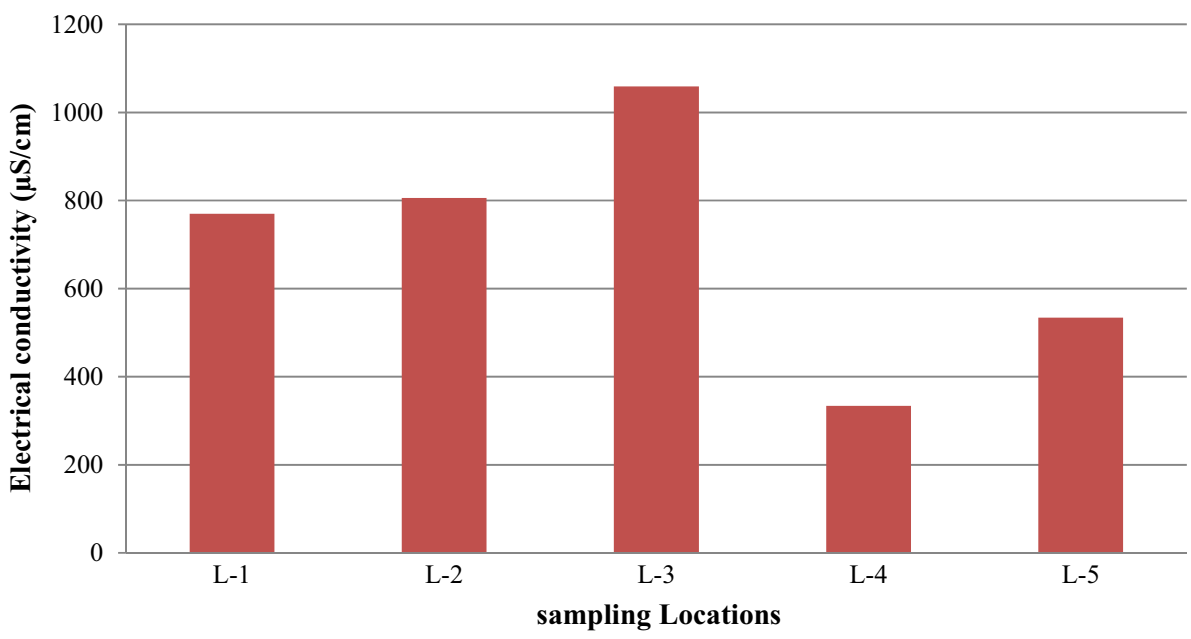

measurements are employed to monitor desalination plants and to decide the extent of intrusion of sea water into groundwater. Conductivity data are very useful to determine the suitability of water and wastewater for disposal on land. The allowable limit of conductivity in groundwater should be in between 700 and $3000 \mu \mathrm{S} / \mathrm{cm}$ (WHO 2012). Electrical conductivity (EC) of the study area varies from 334 to $1059 \mu \mathrm{S} / \mathrm{cm}$ with a mean value of $700 \mu \mathrm{S} / \mathrm{cm}$ (Fig. 5).

\section{Sodium}

Sodium salts produce foam in steam boilers. Sodium is a naturally occurring element in groundwater. High concentration of sodium in groundwater causes heart problem and cardiovascular problems. Concentration of sodium less than $20 \mathrm{mg} / \mathrm{L}$ is recommended for high-risk peoples. The allowable limit of sodium in drinking water is $200 \mathrm{mg} / \mathrm{L}$ (WHO 2012). The sodium concentration of the study area varies from 66 to $333 \mathrm{mg} / \mathrm{L}$ with a mean value of $175 \mathrm{mg} / \mathrm{L}$ (Fig. 4).

\section{Potassium}

Higher concentration of potassium indicates a laxative affect. It causes kidney diseases or other problems such as heart disease, hypertension, diabetes and coronary artery diseases. The allowable limit of potassium is $1-8 \mathrm{mg} / \mathrm{L}$ (WHO 2012). The potassium concentration of the study area varies from 3 to $8 \mathrm{mg} / \mathrm{L}$ with a mean value of $4.6 \mathrm{mg} / \mathrm{L}$ (Fig. 5).

\section{Calcium}

Calcium of total body is mostly found in teeth and bones. The function of remaining calcium in body serves as vascular contraction, muscle contraction, blood clotting and nerve transmission. Lesser amount of calcium is associated with increased risk of nephrolithiasis, osteoporosis, hypertension, colorectal cancer and coronary artery diseases obesity and insulin resistance. High content of calcium and magnesium in drinking water should be avoided in the case of kidney stone or bladder stone. The acceptable limit of calcium in drinking water is $75 \mathrm{mg} / \mathrm{L}$ (WHO 2012). The calcium
Fig. 6 Variation of $\mathrm{K}^{+}$and $\mathrm{Fe}^{2+}$ concentrations at different locations of the present study

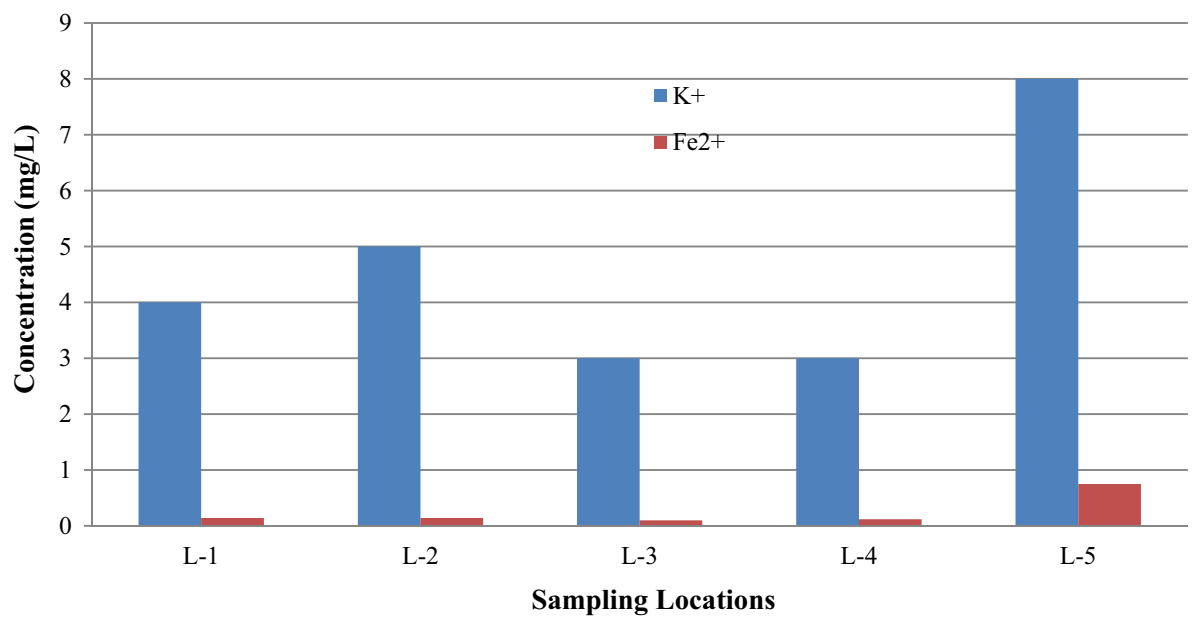

Sampling Locations 
concentration of the study area varies from 30 to $53 \mathrm{mg} / \mathrm{L}$ with a mean value of $42 \mathrm{mg} / \mathrm{L}$ (Fig. 4).

\section{Magnesium}

Magnesium is found inside the earth surface due to the dissolution of magnesium-rich minerals. Magnesium plays an important role in ATP, metabolism, glycolysis, transport of element such as $\mathrm{Ca}, \mathrm{Na}$ and $\mathrm{K}$ through membranes, synthesis of nucleic acids and proteins, muscles contraction and neuromuscular excitability etc. The deficiency of magnesium increases risks to human health and results in hypertension, vasoconstrictions, atherosclerotic vascular disease, cardiac, eclampsia in pregnant women, acute myocardial in infection and osteoporosis etc. Magnesium concentration greater than $125 \mathrm{mg} / \mathrm{L}$ may shows laxative affects. The allowable limit of magnesium in drinking water is $30 \mathrm{mg} / \mathrm{L}$ (WHO 2012). The magnesium concentration of the study area varies from 12 to $41 \mathrm{mg} / \mathrm{L}$ with a mean value of $25 \mathrm{mg} / \mathrm{L}$ (Fig. 4).

\section{Carbonate and bicarbonate}

High concentration of alkalinity in water is harmful for irrigation purpose as it leads to soil damage and reduces crop yields. The permissible limit of alkalinity in drinking water is $200 \mathrm{mg} / \mathrm{L}$ as per WHO (2012). Taste of water becomes unpleasant on high concentration of alkalinity. The carbonate concentration of the study area varies from 0 to $453 \mathrm{mg} / \mathrm{L}$ with a mean value of $154 \mathrm{mg} / \mathrm{L}$. The concentration of bicarbonate varies from 96 to $458 \mathrm{mg} / \mathrm{L}$ with a mean of value of $227 \mathrm{mg} / \mathrm{L}$ (Fig. 3).

\section{Iron}

Dissolution of rock and minerals, landfill leachates, acid mine, drainage, sewage and industrial effluents is responsible for the presence of iron in groundwater. The allowable limit of iron in drinking water is $0.3 \mathrm{mg} / \mathrm{L}$ (WHO 2012). The iron concentration of the study area of all the samples varies from 0.10 to $0.75 \mathrm{mg} / \mathrm{L}$ with a mean value of $0.425 \mathrm{mg} / \mathrm{L}$ (Fig. 6).

\section{Irrigation suitability}

\section{Soluble sodium percentage (SSP or $\mathrm{Na} \%$ )}

Percentage of $\mathrm{Na}^{+}$or SSP content is a guideline to assess suitability for agricultural purpose. SSP value less than 200 is considered suitable for irrigation purpose. SSP is determined and summarized in Table 2 which ranges from 46 to 85. The SSP values of all the locations lie within the range as prescribed for suitability for agricultural use.

\section{Sodium adsorption ratio (SAR)}

The utility of groundwater for irrigation purpose is determined with the help of salinity and SAR. The SAR value should be less than 20 for the groundwater to be used for irrigation. SAR values for the same have been determined and are tabulated in Table 2. SAR values as determined in the present study lie in the range from 2 to 13 . The SAR values of all the samples determined in present study are found to be well within the permissible limits mentioned above.

\section{Residual sodium carbonate (RSC)}

The quality of groundwater assessed in terms of alkaline earth with weak acids is expressed in terms of RSC. The permissible limit values suitable for irrigation purpose range from 1.25 to 2.50 . However, the values greater than 2.50 are considered to be unsuitable for irrigation purposes. RSC values of the study area are shown in Table 2. All the samples lie in the range of $0.21-14.35$. Therefore, from Table 3 , it can be concluded that $60 \%$ groundwater samples of the study area fall in marginally suitable or good category and remaining $40 \%$ samples of the area fall in unsuitable category.

\section{Magnesium adsorption ratio (MAR)}

The relationship between magnesium and calcium concentration in groundwater is determined by magnesium adsorption ratio (MAR). MAR value greater than 50 is considered unsuitable for irrigation purposes. MAR has been calculated and is summarized in Table 2 which ranges from 39 to 60.
Table 2 Water quality indices of groundwater samples of different sampling locations

\begin{tabular}{llrrrrr}
\hline Location & SSP & SAR & RSC & MAR & KR & PI \\
\hline L-1 & 63.12 & 5.17 & 0.21 & 43.38 & 1.69 & 80.39 \\
L-2 & 62.66 & 5.22 & 4.98 & 47.00 & 1.65 & 71.77 \\
L-3 & 85.39 & 12.98 & 14.35 & 38.95 & 5.81 & 93.05 \\
L-4 & 48.44 & 2.29 & 1.99 & 49.04 & 0.91 & 76.04 \\
L-5 & 46.23 & 2.77 & 1.86 & 60.28 & 0.82 & 71.80 \\
\hline
\end{tabular}

$S S P$ soluble sodium percentage, $S A R$ sodium adsorption ratio, $R S C$ residual sodium carbonate, MAR magnesium adsorption ratio, $K R$ Kelly's ratio, $P I$ permeability index 
Table 3 Samples classification as per specified standards for different water quality parameters

\begin{tabular}{|c|c|c|c|c|}
\hline Parameters & Range & Class & No. of samples & $\begin{array}{l}\text { Percentage } \\
\text { of samples }\end{array}$ \\
\hline \multirow[t]{2}{*}{ SSP } & $<200$ & Suitable & 5 & 100 \\
\hline & $>200$ & Unsuitable & 0 & 0 \\
\hline \multirow[t]{5}{*}{ SAR } & $<20$ & Excellent & 5 & 100 \\
\hline & $20-40$ & Good & 0 & 0 \\
\hline & $40-60$ & Permissible & 0 & 0 \\
\hline & $60-80$ & Doubtful & 0 & 0 \\
\hline & $>80$ & Unsafe & 0 & 0 \\
\hline \multirow[t]{3}{*}{ RSC } & $<1.25$ & Safe & 1 & 20 \\
\hline & $1.25-2.50$ & Marginally suitable & 2 & 40 \\
\hline & $>2.50$ & Unsuitable & 2 & 40 \\
\hline \multirow{2}{*}{$\begin{array}{l}\text { MAR (Kacmaz and } \\
\text { Nakoman 2010) }\end{array}$} & $<50$ & Suitable & 4 & 80 \\
\hline & $>50$ & Unsuitable & 1 & 20 \\
\hline \multirow[t]{2}{*}{$\mathrm{KR}$} & $<1$ & Suitable & 2 & 40 \\
\hline & $>1$ & Unsuitable & 3 & 60 \\
\hline \multirow[t]{3}{*}{ PI } & $<80$ & Good & 3 & 60 \\
\hline & $80-100$ & Moderate & 2 & 40 \\
\hline & $100-120$ & Poor & 0 & 0 \\
\hline \multirow[t]{5}{*}{ EC } & $<250$ & Excellent & 0 & 0 \\
\hline & $250-750$ & Good & 2 & 40 \\
\hline & $750-2000$ & Permissible & 3 & 60 \\
\hline & $2000-3000$ & Doubtful & 0 & 0 \\
\hline & $>3000$ & Unsuitable & 0 & 0 \\
\hline \multirow[t]{4}{*}{ TH } & $<75$ & Soft & 0 & 0 \\
\hline & $75-150$ & Moderate & 1 & 20 \\
\hline & $150-300$ & Hard & 1 & 20 \\
\hline & $>300$ & Very hard & 3 & 60 \\
\hline \multirow[t]{8}{*}{ Chloride } & $<0.14$ & Extremely fresh & 0 & 0 \\
\hline & $0.14-0.84$ & Very fresh & 0 & 0 \\
\hline & $0.84-4.23$ & Fresh & 0 & 0 \\
\hline & $4.23-8.46$ & Fresh brackish & 0 & 0 \\
\hline & $8.46-28.21$ & Brackish & 0 & 0 \\
\hline & $28.21-282.1$ & Brackish salt & 5 & 100 \\
\hline & $282.1-564.3$ & Salt & 0 & 0 \\
\hline & $>564.3$ & Hyperthaline & 0 & 0 \\
\hline
\end{tabular}

The obtained MAR values compared with standard values are summarized in Table 3. It can be concluded that about $80 \%$ of water samples are suitable whereas $20 \%$ of the samples are unsuitable for irrigation purpose.

\section{Kelley's ratio (KR)}

Excess amount of sodium over calcium and magnesium is determined by using Kelley's ratio (KR). KR value less than 1 indicates the suitability of the groundwater for irrigation purpose. The KR values of the study area of all the locations have been determined and are tabulated in Table 2. The KR value of all the samples ranges from 0.82 to 5.8. The obtained KR values compared with standard values are summarized in Table 3. It can be concluded that $40 \%$ water is suitable and $60 \%$ of water samples are found to be unsuitable for irrigation purposes.

\section{Permeability index (PI)}

The long-term use of irrigation water affects sodium, calcium, magnesium and carbonate content in the soil. These contents, in turn, affect the permeability of soil. PI value less than 80 is used for irrigation purpose. The PI values of the study area of all the samples have been assessed and are summarized in Table 2. The PI values of all the samples in the present study range from 72 to 93 . The standard values depicted through Table 3 indicate that $60 \%$ of groundwater 
samples fall in good category whereas $40 \%$ samples fall in moderate category for the irrigation use.

\section{Conclusion}

The study of hydrochemical parameters reports that the shallow groundwater aquifers of the study area indicate that the groundwater is safe for drinking and irrigation purposes. The groundwater quality reveals that $\mathrm{pH}, \mathrm{TH}$ and TDS are safe for drinking purposes. Other elements are within the permissible limits except one place where iron is moderately high. SAR and SSP values fall in excellent category which makes the groundwater suitable for agriculture activities. MAR and PI also fall in good permissible categories. RSC and KR fall in suitable category. Above conclusion reveals that the groundwater of study area is suitable for drinking and irrigation purposes.

Open Access This article is distributed under the terms of the Creative Commons Attribution 4.0 International License (http://creativeco mmons.org/licenses/by/4.0/), which permits unrestricted use, distribution, and reproduction in any medium, provided you give appropriate credit to the original author(s) and the source, provide a link to the Creative Commons license, and indicate if changes were made.

\section{References}

Aghazadeh N, Mogaddam AA (2002) Assessment of groundwater quality and its suitability for drinking and agricultural uses in the Oshnavieh area, Northwest of Iran. J Environ Prot 1:30-40

Ahmed AA (2007) Using lithologic modeling techniques for aquifer characterization and groundwater flow modeling of Sohag area, Egypt. In: Second international conference on geo-resources in the Middle East and North Africa, 24-28 Feb 2007. Cairo University, Egypt

Ahmed SS, Mazumder H, Jaham CS, Islam Ahmed (2002) Hrdrochemistry and classification of groundwater, Rajshahi City Corporation Area, Bangladesh. J Geol Soc Ind 60:411-418

Al-Futaisi A, Rajmohan N, Al-Tauqi S (2007) Groundwater quality monitoring in and around Barka dumping site, Sultanate of Oman. In: The second IASTED (The International Association of Science and Technology for Development) international conference on water resources management (WRM2007), Honolulu, Hawaii, 20-22 Aug

APHA (1999) Standard methods for the examination of water and waste waters. American Public Health Association, American Water Works Association, Water Environment Federation, Alexandria

Arajhi A, Beecham S, Bolan NS, Hassanli A (2015) Evaluation of soil chemical properties irrigated with recycled wastewater under partial root-zone drying irrigation for sustainable tomato production. Agric Water Manag 161:127-135. https://doi.org/10.1016/j. Agwat.2015.07.013

Ayers RS, Westcot DW (1985) Water quality for agriculture, FAO irrigation and drainage Paper 29. Rev. I. UN Food and Agriculture Organization, Romeo

Balaji E, Nagaraju A, Sreedhar Y, Thejaswi A, Sharifi Z (2016) Hydrochemical characterization of groundwater in around Tirupati area,
Chittoor district, Andhra Prasdes, South India. Appl Water Sci. https://doi.org/10.1007/s13201-016-0448-6

Bathrellos GD, Skilodimon HD, Kelepertsis A, Alexakis D, Chrisanthakil Archonti D (2008) Environmental research of groundwater in the urban and suburban areas of Attica region, Greece. Environ Geol 56:11-18

Bhuiyan MAH, Ganyaglo S, Suzuki S (2015) Reconnaissance on the suitability of the available water resources for irrigation in Thakurga on district of northwestern Bangladesh. Appl Water Sci 5(3):229239. https://doi.org/10.1007/s13201-014-0184-8

Brindha K, Elango L (2010) Study on bromide in groundwater in parts of Nalgonda district, Andhra Pradesh, India. Earth Sci India 3(1):73-80

Brindha K, Elango L (2011) Hydrochemical characteristics of groundwater for domestic and irrigation purposes in Madhuranthakam, Tamil Nadu, India. Earth Sci Res J 15(2):101-108

Brindha K, Rajesh R, Murugan R, Elango L (2011) Fluoride contamination groundwater in parts of Nalgonda district, Andhra Pradesh, India. Environ Monit Assess 172:481-492

Brown RM, McClelland NI, Deininger RA, Tozer RG (1970) A water quality index do we dare. Water Sewage Works 117(10):339-343

CGWB (Central Ground Water Board) (2010), Annual report, Ministry of Water Resources, Government of India

Chapman D (1996) Water quality assessments-a guide to use of biota, sediments and water in environmental monitoring, 2nd edn. University Press, Cambridge (ISBN 0419205905 (HB) 0419216006 (PB))

Doneen LD (1964) Water quality for agriculture. Department of Irrigation, University of California, Davis, p 48

Franson MAH (1992) Standard methods: for the examination of water and wastewater, 18th edn. American Public Health Association, American Water Works Association, Water Environment Federation

Greater Noida Master Plan, 2001, 2021 plan report (2013), Greater Noida Authority

https://en.wikipedia.org/wiki/Greater_Noida. Accessed 4 May 2016

Hem JD (1991) Study and interpretation of the chemical characteristics of natural waters, 3rd edn. Scientific Publishers, Jodhpur (Book 2254)

Ishaku JM, Ahmed AS, Abubak MA (2011) Assessment of groundwater quality using chemical indices and GIS mapping in Jada area, Northeastern Nigeria. J Earth Sci Geotech Eng 1(1):35-60

Islam MA, Zahid A, Rahman MM, Rahman MS, Islam MJ, Akter Y, Shammi M, Bodrud-Doza M, Roy B (2016a) Investigation of groundwater quality and its suitability for drinking and agricultural use in the south central part of the coastal region in Bangladesh. Expo health. https://doi.org/10.1007/s12403-016-0220-z

Islam SMD, Majumder RK, Uddin MJ, Khalil MI, Alam MF (2016b) Hydrochemical characteristics and quality assessment of groundwater in Patuakhali district, southern coastal region of Bangladesh. Expo Health. https://doi.org/10.1007/s1240 3-016-0221-y

Jalali M (2002) Geochemistry characterization of groundwater in an agricultural are of Razan, Hamadan, Iran. Environ Geol $56: 1479-1488$

Jalali M (2007) Hydrochemical identification of groundwater N resources and their changes under the impacts of human activity in the Chah basin in western Iran. Environ Monit Assess 130:347-364

Kacmaz H, Nakoman ME (2010) Hydrochemical characteristics of shallow groundwater aquifer containing Uranyl phosphate minerals in the Koprubasi (Manisa) area, Turkey. Environ Earth Sci 59:449-457

Kelley JE Jr (1963) The critical path method resources planning and scheduling. Ind Sched 13:347365 
Kumar SK, Logeshkumaran A, Magesh NS, Godson PS, Chandrasekar N (2005) Hydro-geochemistry and application of water quality index (WQI) for groundwater quality assessment, Anna Nagar, part of Chennai City, Tamil Nadu, India. Appl Water Sci 5:335343. https://doi.org/10.1007/s13201-014-0196-4

Lloyd JW (1999) Water resources of hard rock aquifers in arid and semi-arid zones. Studies and reports in hydrology. UNESCO, Paris

Mangukiya R, Bhattacharya T, Chakraborty S (2012) Quality characterization of groundwater using water quality index in Surat city, Gujarat, India. Int Res J Environ Sci 1(4):14-23

Manjusree TM, Joseph S, Thomas J (2009) Hydrogeochemistry and groundwater quality in the coastal sandy clay aquifers of Alappuzha district, Kerela. J Geol Soc Indian 74:459-468

Milovanovic M (2007) Water quality assessment and determination of pollution sources along the Axios/Vardar River, Southeast Europe. Desalination 213:159-173

Montety VD, Radakovitch O, Vallet- Coulmb C, Blavoux B, Hermitte D, Valley V (2008) Origin of groundwater salinity and hyrogeochemical processes in a confined coastal aquifer: case of the Rho ne delta (Southern France). Appl Geochem 23:2337-2349

Mukherjee S, Das AK (2007) Groundwater quality assessment for irrigation and domestic uses in Raigad districts, Maharahtra, India. J Earth Sci 1(1):66-81

Muntean C, Petru N, Mihaela C, Lavinia L, Ioan U, Giannin M, Ramona G (2006) Studies regarding the ground water pollution in a rural area. Chem Bull Politeh 51(65):75-78

Nag SK (2014) Evaluation of hydrochemical parameters and quality assessment of the groundwater in Gangajal ghati Block, Bankura district, West Benagal, Indi. Arab J Sci Eng 39:5715-5727

Nag SK, Ghosh P (2013) Variation in groundwater levels and water quality in Chhatna Block, Bankura district, West Bengal A GIS approach. J Geol Soc Indian 81(2):261-280

Nag SK, Ray S (2015) Hydrochemical evaluation of groundwater quality of Bankura I and II Blocks, Bankura district, West Bengal, India: emphasis on irrigation and domestic utility. Arab J Sci Eng 40:205-2014

Nagaraju A, Sunil Kumar K, Thejaswi A (2014) Assessment of groundwater quality for irrigation: a case study from Bandalamottu lead mining area, Guntur district, Andhra Pradesh, South India. Appl Water Sci 4:385-396. https://doi.org/10.1007/s13201-014-0154-1

Pritchard M, Mkandawire T, O'Neill JG (2008) Assessment of groundwater quality in shallow wells within the solution districts of Malawi. Phys Chem Earth 33:812-823
Ragunath HM (1987) Groundwater. Wiley Eastern, New Delhi, p 563

Ramesh K, Elango L (2005) Groundwater quality assessment in Tondiar basin. Indian J Environ Prot 26(6):497-504

Rao NS, Subrahmanyam A, Kumar SR, Srinivasulu N, Rao GB, Rao PS, Reddy GV (2012) Geochemistry and quality of groundwater of Gummanampadu sub-basin, Guntur district, Andhra Pradesh, India. Environ Earth Sci 67(5):1451-1471

Rivers CN, Hiscock KM, Feast NA, Barrett MH, Dennis PF (1996) Use of nitrogen isotopes to identify nitrogen contamination of the Sherwood sandstone aquifer beneath the city of Nottingham, UK. Hydrol J 4(1):90-102

Sivasubramanian P, Balasubramanian N, Soundranayagam JP, Chandrasekar N (2013) Hydrochemical characteristics of coastal aquifers of Kadaladi, Ramanathapuram district, Tamil Nadu, India. Appl Water Sci 3:603-612

Sreedevi PD (2002) Groundwater quality of Pageru river basin, Cuddapah district, Andhra Pradesh. J Geol Sci India 64:619-636

Stites W, Kraft GJ (2002) Nitrate and chloride loading groundwater from an irrigated North-Central U.S. Sand-plain vegetable field. J Environ Qual 30:1176-1184

Thilagavathi R, Chidambaram S, Prasanna MV, Singaraja C (2012) A study on groundwater geochemistry and water quality in layered aquifers system of Pondicherry region, southeast India. Appl Water Sci 2:253-269. https://doi.org/10.1007/s13201-012-0045-2

Tiwari Seema (2015) Water quality parameters-a review, Bhopal, India. Int J Eng Sci Invent Res Dev 1(9):319-324

Todd DK (1980) Grounwater hydrology. Wiley, New York, pp 10-138 Vasanthavigar M, Srinivasamoorthy K, Vijayaragavan K, Rajiv Ganthi R, Chidambaram S, Anandhan P, Manivannan R, Vasudevan S (2010) Application of water quality index for groundwater quality assessment: Thirumanimuttar Sub-basin, Tamilnadu, India. Environ Monit Assess 171(1-4):595-609

WHO (2012) Guidelines for drinking water, recommendations. World Health Organizations, Geneva

Wilcox LV (1955) Classification and use of irrigation waters, vol 969. U.S. Dept. of Agriculture, Washington, D.C.

Wright EP, Burgess WG (eds) (1992) The hydrogeology of crystalline basement aquifers in Africa. Geological Society, London

Publisher's Note Springer Nature remains neutral with regard to jurisdictional claims in published maps and institutional affiliations. 